\title{
PENINGKATAN KESEHATAN PADA REMAJA PAROKI KATEDRAL SAMARINDA TAHUN 2018
}

\author{
${ }^{1}$ Elfina Natalia, ${ }^{2}$ Maria Floriana Ping, ${ }^{3}$ Yessy Cristianto, ${ }^{4}$ Yulieta Lehyun Jho \\ 1,2,3,4 Program studi Diploma III Keperawatan, STIKES \\ DIRGAHAYU SAMARINDA, Jl. Pasundan No 21 \\ e-mail: elfina.natalia@gmail.com
}

\begin{abstract}
ABSTRAK
Dalam siklus kehidupan, masa remaja merupakan masa keemasan. Pada masa ini terjadi banyak perubahan dan masalah, yang jika tidak cepat di tangani akan menjadi masalah yang berkepanjangan dan berdampak serius. Tujuan program kemitraan ini adalah sebagai tindakan preventif dan promotif bagi para remaja yang berada di Lingkungan Keuskupan Agung Samarinda khususnya di Paroki Katedral. Metode yang digunakan dalam kegiatan ini adalah penyuluhan kesehatan langsung melalui pendekatan Didaktik dan Sokratik serta pemeriksaan kesehatan, yang dilakukan sebanyak enam kali dengan tema setiap penyuluhan berbeda sesuai dengan kebutuhan akan informasi mengenai kesehatan dari peserta. Hasil dari program kemitraan ini adalah membantu remaja memiliki informasi yang memadai tentang masalah kesehatan, sehingga direkomendasikan intervensi ini dapat diaplikasikan sebagai salah satu edukasi yang membantu remaja diparoki Katedral mampu mengambil keputusan terkait dengan kesehatannya yang tepat tanpa tekanan dan paksaan.
\end{abstract}

Kata Kunci: Peningkatan Kesehatan, Remaja, Paroki Katedral

\begin{abstract}
In the life cycle, adolescence is a golden period. During this time there were many changes and problems, which if not quickly dealt with would be a prolonged problem and have a serious impact. The purpose of this partnership program is as a preventive and promotive measure for young people who are in Samarinda Archdiocese, especially in the Cathedral Parish. The method used in this activity was direct health education through a Didactic and Socratic approach and health checks, which were conducted six times with the theme of each extension differing according to the need for information about the health of the participants. The outcome of this partnership program is to help adolescents have adequate information about health issues, so it is recommended that this intervention can be applied as an education that helps adolescents in the cathedral be able to make decisions related to their proper health without pressure and coercion.
\end{abstract}

Keywords: Health Improvement, Youth, Cathedral Parishes 


\section{PENDAHULUAN}

Dalam siklus kehidupan, masa remaja merupakan masa keemasan. Pada masa ini terjadi banyak perubahan dan masalah, yang jika tidak cepat di tangani akan menjadi masalah yang berkepanjangan dan berdampak serius. Salah satu masalah remaja yang memerlukan perhatian adalah masalah kesehatan, dimana kesehatan merupakan elemen penting manusia untuk dapat hidup produktif. Remaja yang sehat adalah remaja yang produktif sesuai dengan tingkat perkembangannya.

Remaja adalah harapan bangsa, sehingga berlebihan jika dikatakan bahwa masa depan bangsa yang akan datang akan ditentukan pada keadaan remaja saat ini masa remaja merupakan masa peralihan dari masa anak-anak ke masa dewasa. Masa ini sering disebut dengan masa pubertas. Dimana menurut menurut Hurlock (1993), masa yang penuh dengan kegoncangan, taraf mencari identitas diri dan merupakan periode yang paling berat.

Keadaan tersebut menunjukkan bahwa betapa remaja membutuhkan bantuan guna menyelesaikan permasalahan permasalahan kesehatan yang dihadapinya melalui pengambilan keputusan yang tepat sehingga tidak merugikan dirinya maupun masa depannya. Salah satu upaya yang dapat dilakukan untuk membantu melalui penyuluhan kesehatan, yaitu kegiatan penambahan pengetahuan yang diperutukkan bagi masyarakat melalui penyebaran pesan, dengan tujuan mempengaruhi perilaku masyarakat baik itu secara individu atau pun kelompok dengan menyampaian pesan.

Paroki Katedral samarinda khususnya di Seminari Don Bosco dan Asrama Putri Kartini dapat secara bersinergi bekerja sama dengan institusi kesehatan yang mempunyai perhatian pada kesehatan remaja, seperti yang diusung dalam Program Kemitraan Masyarakat oleh STIKES Dirgahayu Samarinda.
Diharapkan kerjasama dengan dua mitra (Seminari Don Bosco dan Asrama Putri Kartini) dapat membantu remaja agar memiliki informasi yang memadai tentang masalah kesehatan, sehingga mereka mampu mengambil keputusan yang tepat tanpa tekanan dan paksaan.

\section{METODE}

Program kemitraan ini menggunakan metode penyuluhan kesehatan langsung melalui pendekatan Didaktik dan Sokratik serta pemeriksaan kesehatan. Subjek dalam penelitian ini adalah remaja di wilayah Paroki Katedral. Program kemitraan ini dilakukan di Paroki Katedral Samarinda. Dengan metode penyuluhan dan pemeriksaan kesehatan, yang dilakukan sebanyak enam kali dengan tema setiap penyuluhan berbeda sesuai dengan kebutuhan akan informasi mengenai kesehatan dari peserta.

\section{HASIL dan PEMBAHASAN \\ Kegiatan Program Kemitraan}

1. Pendidikan Kesehatan pada Remaja "Mengenal Diri Sendiri", dengan peserta Remaja Katolik SMA di Keuskupan Agung Samarinda, tempat pelaksanaan kegiatan di Aula Keuskupan Agung Samarinda.

2. Pendidikan Kesehatan pada Remaja "Mengenal Diri Sendiri", dengan peserta Muda-mudi Katolik Keuskupan Agung Samarinda, tempat pelaksanaan kegiatan di Rumah Retret "Bukit Rahmat Putak".

3. Pendidikan Kesehatan "Gizi pada Usia Remaja", dengan peserta siswi-siswi Asrama Kartini Samarinda, tempat pelaksanaan kegiatan di Asrama kartini Samarinda.

4. Pendidikan Kesehatan "Perilaku Hidup Bersih Sehat", dengan peserta Seminaris Sto. Yohanes Don Bosco (SMA), tempat pelaksanaan kegiatan di Seminari 
Don Bosco.

5. Pemeriksaan Kesehatan "kadar Hemoglobin" pada Siswi SMP, dengan peserta Siswi-Siswi Asrama Kartini Samarinda, tempat pelaksanaan kegiatan di Asrama kartini Samarinda.

6. Pemeriksaan Kesehatan "kadar Hemoglobin" pada Siswi SMA, dengan peserta Siswi-Siswi Asrama Kartini Samarinda, tempat pelaksanaan kegiatan di Asrama kartini Samarinda.

Kegiatan program kemitraan ini dilakukan enam kali dengan tema setiap penyuluhan berbeda sesuai dengan kebutuhan akan informasi mengenai kesehatan dari peserta.

Tabel 1. Alat dan Bahan Pendidikan Kesehatan Peningkatan Kesehatan Pada Remaja Paroki Katedral

\begin{tabular}{llc}
\hline No & Alat dan Bahan & $\mathrm{n}$ \\
\hline 1. & LCD & 1 \\
2. & Leaflet & 160 \\
3. & Poster & 4 \\
\hline
\end{tabular}

\section{PEMBAHASAN}

Hasil dari program ini membantu remaja memiliki informasi yang memadai tentang masalah kesehatan yang kerap kali dialami oleh para remaja khususnya di wilayah paroki Katedral. Hal ini menunjukkan kombinasi pengalaman belajar merangsang penyesuaian secara sukarela dari perilaku yang sesuai dengan kesehatan. Penekanannya berdasar sukarela dan kesadaran dalam penyesuaian perilaku untuk memajukan kesehatan.

Hal ini sejalan dengan tujuan dari dilakukannya penyuluhan kesehatan yang dikemukakan oleh Notoatmodjo (2010), yakni peningkatan pengetahuan masyarakat di bidang kesehatan, tercapainya perubahan perilaku, individu, keluarga, dan masyarakat sebagai sasaran . utama penyuluhan kesehatan dalam? membina perilaku sehat dan lingkungan sehat serta berperan aktif dalam upaya 3 . meningkatkan derajat kesehatan yang optimal sesuai dengan konsep sehat sehingga dapat menurunkan angka kesakitan dan kematian.

Hasil program Kemitraan ini sejalan dengan sejalan dengan Penelitian yang dilakukan oleh Pramita (2013), yang meneliti Pengaruh Penyuluhan Kesehatan Terhadap Tingkat Pengetahuan Dan Sikap Remaja Tentang Penyakit Menular Seksual di SMPN 2 Wlingi, hasil penelitian menunjukkan adanya peningkatan remaja yang berpengetahuan baik dari 110 remaja (39\%) menjadi 225 remaja $(90 \%)$ dan peningkatan sikap baik dari 11 remaja (4\%) menjadi 80 remaja (28\%). Hasil penelitian diatas menunjukkan bahwa terjadi perubahan nilai rata-rata sikap. Perubaha sikap remaja di SMP BAZNAS Prov.Sul-Sel karena adanya pemberian informasi, dimana didalamnya terdapat proses belajar yang dapat merubah sikap dari yang kurang baik menjadi lebih baik.

Selain metode penyuluhan kesehatan kombinasi yang dilakukan, Media Penyuluhan Kesehatan yang digunakan juga mempunyai peranan penting dalam tercapainya tujuan program kemitraan ini, dimana media yang digunakan oleh tim adalah berupa slide, poster dan leaflet.

Menurut Andersen, Medaglia, dan Henriksen (2012), metode penyuluhan kesehatan langsung berupa diskusi, panel, curah pendapat, demonstrasi, simulasi, bermain peran dan lain sebagainya yang dilakukan langsung antara penyuluh dan peserta (face to face) baik satu arah maupun dua arah memiliki keuntungan bagi peserta karena dapat langsung menunjukkan ekspresi selama proses dan langsung dapat dilihat kemampuan keterampilan, serta dituntut keaktifan dari peserta.

Selain itu menurut Depkes (2008) alat peraga yang digunakan secara baik dapat memberikan keuntungan-keuntungan :

Menghindari salah pengertian.

Memperjelas apa yang diterangkan dan dapat lebih mudah ditangkap.

Menarik serta lebih memusatkan perhatian. 


\section{KESIMPULAN DAN SARAN}

Hasil dari program kemitraan ini adalah membantu remaja memiliki informasi yang memadai tentang masalah kesehatan, sehingga direkomendasikan intervensi ini dapat diaplikasikan sebagai salah satu edukasi yang membantu remaja diparoki Katedral mampu mengambil keputusan terkait dengan kesehatannya yang tepat tanpa tekanan dan paksaan. Saran bagi program kemitraan selanjutnya rekomendasi ini dapat menjadi dasar dalam membuat program baru yaitu pembinaan penyuluh sebaya.

\section{UCAPAN TERIMA KASIH}

1. Ketua Yayasan Setia Budi Samarinda yang memberikan arahan dan dorongan untuk melakukan penelitian ini

2. Ketua Stikes Dirgahayu Samarinda untuk dukungan dalam program kemitraan ini

3. Ketua UPPM atas arahan dalam pengajuan proposal sampai penyelesaian laporan program kemitraan.

\section{DAFTAR PUSTAKA}

Almatsier, S (2009). Prinsip Dasar Ilmu Gizi. Jakarta: Gramedia Pustaka Utama

Arisman (2007) Gizi Dalam Daur Kehidupan. Buku Ajar Ilmu Gizi. Jakarta: EGC

Corwin, Elizabeth J (2009) Handbook of Pathophysiologi, $3^{\text {rd }} \quad E d$. Jakarta:EGC

Fatmah (2009) Anemia Gizi dan Kesehatan Masyarakat. Jakarta: Raja Grafindo Persada

Guyton A. C (2010) Buku Ajar Fisiologi Kedokteran, Alih Bahasa Ken Ariata Tangadi, dkk Jakarta: EGC

Kirana, Dian Purwitaningtyas (2011) Hubungan Asupan Zat Gizi dan Pola Menstruasi dengan Kejadian Anemia pada Remaja Putri di SMAN 2

Semarang. Skripsi. Universitas Diponegoro Program Studi Ilmu Gizi Prawirohardjo, Sarwono (2011) Ilmu Kebidanan. Jakarta:PT Bina Pustaka Sarwono Prawirohardjo 